\title{
Loop die waarheid soms net vir kwaadgeld rond?
}

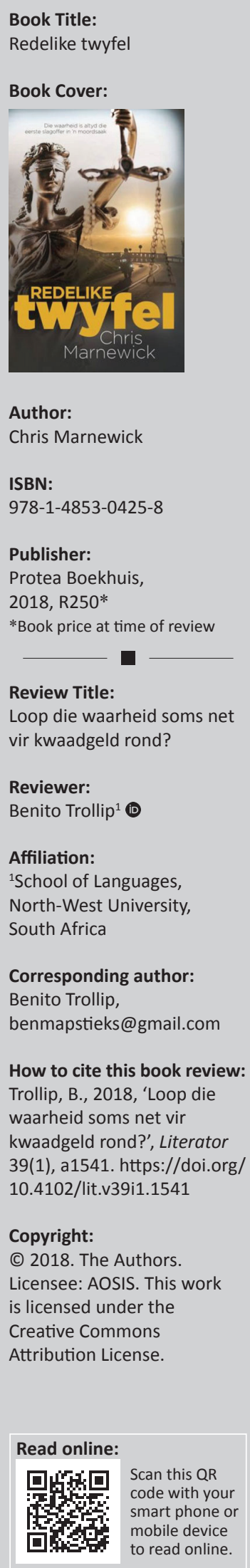

Charles Mouton, 'n gerekende senior advokaat, word van die moord op sy apteker-vrou, Marguerite Mouton, aangekla. Marguerite is op 'n geheimsinnige manier vermoor en Charles kan niks van die aand van haar dood onthou nie. Hulle drie volwasse kinders het klaar besluit hulle pa is skuldig en woon nie die hofverrigtinge by nie. Tydens sy hofsaak het Charles geen behoefte om homself te verdedig nie, maar hy wil net graag self agter die kap van die byl kom. Die persoon wat die ywerigste agter die waarheid aan is, is Manon Viljoen wat aangestel is as ' $n$ vriend van die hof wie se taak dit is om relevante feite bymekaar te maak ten einde 'n regverdige verhoor te bewerkstellig. Die regter wat haar aanstel, is ene Nantes Castel, 'n ou universiteitsliefde, wat 'n reeds spannende situasie net verder kompliseer.

Die waarde van Marnewick se roman lê in die regsfilosofiese besinnings wat hy by monde van sentrale karakters vir die leser aanbied. Een voorbeeld hiervan is wanneer Manon onthou dat Charles een keer in 'n lesing gesê het dat die kosmiese waarheid dit is wat werklik gebeur het, terwyl 'n hof slegs in die '... veronderstelde waarheid wat die getuienis bewys' belang stel (bl. 100). Hierdie soort stellings (en soms retoriese vrae) het my aan A little life (2015) van Hanya Yanagihara herinner waarin soortgelyke idees via karakters wat regsgeleerdes is, voorgehou word. Een voorbeeld is waar Jude oor die aard van die reg teenoor die aard van wiskunde besin (Yanagihara 2015:123):

And also, I guess, that law isn't actually about truth: it's about governance. But math doesn't have to be convenient, or practical or managerial - it only has to be true.

Myns insiens sou Redelike twyfel by 'n uitgebreide toneel waarin die sentrale karakters oor die aard van hulle beroep in gesprek tree, gebaat het. Daar word op bladsy 323 in hierdie rigting beweeg, maar die situasie vorder nie verder as een karakter se duidelike ontnugtering met hulle keuse van beroep nie.

Daar is ongelukkig 'n paar haakplekke in die roman, maar dit is nie van so 'n aard dat die storielyn belemmer word nie. Die liefdesverhaal wat sporadies en eksklusief deur die perspektief van Manon vertel word, is een van die aspekte van die roman wat onoortuigend is. Daar is ook dele soos die een waar Manon motorfiets ry en vir lesse gaan om te leer hoe om veilig met ' $n$ motorfiets te val, wat nie suksesvol tot die romangegewe of die karakterisering bydra nie. Die meeste karakters (met die uitsondering van Manon en Charles), kom ook nie tot hulle reg wat karakterisering betref nie. Persoonlik was ek erg nuuskierig oor die aandeel van Charles se skoonseun (Adam) in die gespanne familiesituasie van die Moutons, maar dit is nie genoegsaam beskryf nie - of die outeur hier opsetlike leemtes vir 'n opvolg gelaat het, is 'n oop vraag.

Marnewick, self 'n voormalige senior advokaat, het subtiel te werk gegaan om 'n ontspanningsroman met enkele interessante vrae oor die aard van en interaksie tussen stilte, waarheid, en die reg te kombineer. Die struktuur van die roman (met afdelings soos 'Kruisverhoor' en 'Slotbetoog' wat met aantekeninge uit lesings wat Charles gegee het, toegelig is) verleen ook op 'n oortuigende wyse 'n sterker hofgevoel aan die roman. As gevolg van die roman se dualistiese aard (as ontspanningsfiksie met ' $n$ regsfilosofiese aanslag), sal die deursnee-fiksieleser, asook lesers wat iets meer as 'n lekkerlees-boek soek, dit waardevol vind. Daar is genoeg afdraaipaaie om 'n leser geïnteresseerd en nuuskierig genoeg te hou om tot aan die einde te bly lees.

In die geheel is die roman oortuigend en ' $n$ welkome bydrae tot die Afrikaanse spanningsfiksielandskap. Die slot is ook nie tipies van 'n roman wat met 'n (oënskynlike) moord begin nie, en dit word verwelkom. Die slot bied, volgens my, beslis die potensiaal vir 'n (hopelik) spannender opvolg.

\section{Literatuurverwysings}

Yanagihara, H., 2015, A little life, Picador, London. 